\title{
Lipase kinetics: hydrolysis of triacetin by lipase from Candida cylindracea in a hollow-fiber membrane reactor
}

Citation for published version (APA):

Guit, R. P. M., Kloosterman, M., Meindersma, G. W., Mayer, M., \& Meijer, E. M. (1991). Lipase kinetics: hydrolysis of triacetin by lipase from Candida cylindracea in a hollow-fiber membrane reactor. Biotechnology and Bioengineering, 38(7), 727-732. https://doi.org/10.1002/bit.260380706

DOI:

10.1002/bit.260380706

Document status and date:

Published: 01/01/1991

Document Version:

Publisher's PDF, also known as Version of Record (includes final page, issue and volume numbers)

Please check the document version of this publication:

- A submitted manuscript is the version of the article upon submission and before peer-review. There can be important differences between the submitted version and the official published version of record. People interested in the research are advised to contact the author for the final version of the publication, or visit the $\mathrm{DOI}$ to the publisher's website.

- The final author version and the galley proof are versions of the publication after peer review.

- The final published version features the final layout of the paper including the volume, issue and page numbers.

Link to publication

\section{General rights}

Copyright and moral rights for the publications made accessible in the public portal are retained by the authors and/or other copyright owners and it is a condition of accessing publications that users recognise and abide by the legal requirements associated with these rights.

- Users may download and print one copy of any publication from the public portal for the purpose of private study or research.

- You may not further distribute the material or use it for any profit-making activity or commercial gain

- You may freely distribute the URL identifying the publication in the public portal.

If the publication is distributed under the terms of Article 25fa of the Dutch Copyright Act, indicated by the "Taverne" license above, please follow below link for the End User Agreement:

www.tue.nl/taverne

Take down policy

If you believe that this document breaches copyright please contact us at:

openaccess@tue.nl

providing details and we will investigate your claim. 


\title{
Lipase Kinetics: Hydrolysis of Triacetin by Lipase from Candida cylindracea in a Hollow-Fiber Membrane Reactor
}

\author{
R.P.M. Guit, M. Kloosterman, G.W. Meindersma, M. Mayer, and E. M. Meijer \\ DSM-Research, 6160 MD Geleen, Netherlands
}

Received June 6, 1990/Accepted January 21, 1991

The aptitude of a hollow-fiber membrane reactor to determine lipase kinetics was investigated using the hydrolysis of triacetin catalyzed by lipase from Candida cylindracea as a model system. The binding of the lipase to the membrane appears not to be very specific (surface adsorption), and probably its conformation is hardly altered by immobilization, resulting in an activity comparable to that of the enzyme in its native form. The reaction kinetics defined on the membrane surface area were found to obey MichaelisMenten kinetics. The specific activity of the lipase in the membrane reactor was found to be significantly higher than in an emulsion reactor. The activity and stability of the enzyme immobilized on a hydrophilic membrane surface seem not to be influenced significantly by the choice of the membrane material. The hollow-fiber membrane reactor is a suitable tool to assess lipase kinetics in a fast and convenient way.

Key words: lipase kinetics - Candida cylindracea $\cdot$ hydrolysis of triacetin $\cdot$ hollow-fiber membrane reactor $\cdot$ immobilization

\section{INTRODUCTION}

Lipases (EC 3.1.1.3) are enzymes that preferentially adsorb at hydrophobic interfaces. Depending on the quality of the interface, the enzyme finds its optimal active conformation to hydrolyze water-insoluble ester compounds. Triglycerides are the natural substrates for lipases. Recently, lipases have been the subject of many investigations, e.g., for the production of pharmaceuticals (Kloosterman ${ }^{6}$ ), flavors, and pesticides (Kamphuis ${ }^{4}$.

Lipase-catalyzed reactions are often examined in emulsion systems. Due to the generation of products, the surface quality continuously changes during the reaction. At a fixed energy input the droplet size distribution and therefore also the amount of interfacial area will continuously change. Because there is no convenient method available to determine the interfacial area along the reaction path, it is still a difficult task to assess lipase kinetics.

Already in 1965 Benzonana $^{1}$ showed that lipase kinetics in emulsion reaction systems obey MichaelisMenten kinetics when the substrate concentration as well as the value for the Michaelis-Menten constant were expressed as interfacial area per volume. Recently, Kierkels ${ }^{5}$ applied successfully a laser technique based on Fraunhofer diffraction to determine continuously the interfacial emulsion area during lipase reaction, but the determination of the droplet size distribution at Biotechnology and Bioengineering, Vol. 38, Pp. 727-732 (1991) (C) 1991 John Wiley \& Sons, Inc. high emulsion concentrations is still a difficult task to perform.

In this article the applicability of a hollow-fiber membrane reactor (Fig. 1) to assess lipase kinetics will be investigated. Important advantages of this reactor are (a) the organic and the aqueous phase remain separated and (b) the lipase is immobilized on the membrane surface and can be applied for a long time. Because of the well-defined plane of reaction, this reactor may be a simple alternative for the emulsion reactor to assess lipase kinetics under the controlled conditions of a fixed interface. To the best of our knowledge, the use of the membrane reactor has never been reported for this purpose.

As a model system, it was decided to study the hydrolysis of triacetin catalyzed by lipase from Candida cylindracea. In this work the enzyme activity in the membrane reactor has been studied as a function of enzyme loading and substrate concentration. Also, enzyme stability and membrane cleaning aspects were studied.

\section{MATERIALS, EQUIPMENT, AND PROCEDURES}

\section{Materials}

The lipase from Candida cylindracea was obtained from Sigma Chemicals Co., triacetin was obtained from

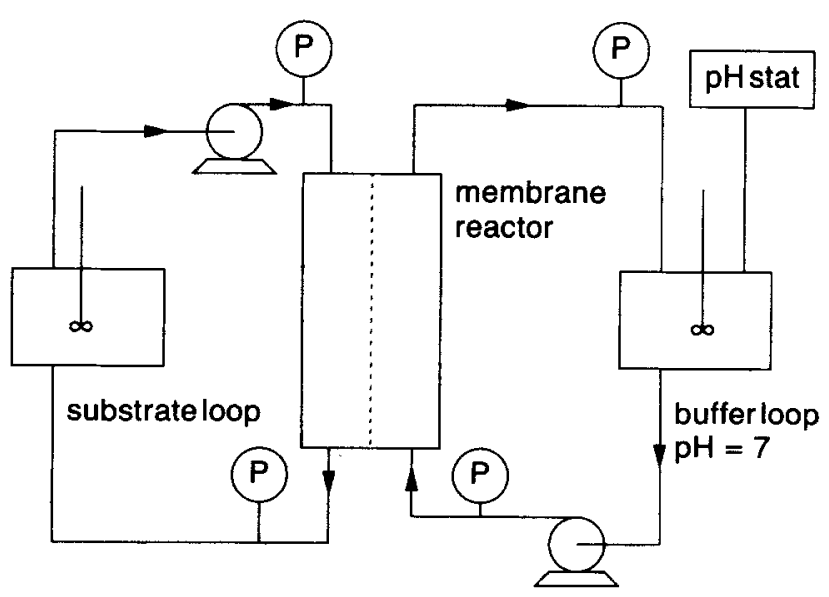

Figure 1. Flow diagram of the used hollow-fiber membrane reactor system. 
Janssen Chimica, and the membrane cleaning detergent, Ultrasil-11, was obtained from Henkel.

\section{Hollow-Fiber Membrane Reactor System}

The membrane reactor used in this study is a commercially available Sepracor membrane reactor model MBR 500-tm. The Sepracor membrane module model TS is a hydrophilic hollow-fiber ultrafiltration membrane (molecular weight cut off $=50,000$ ). The nominal interfacial area of the module is $0.75 \mathrm{~m}^{2}$. The membrane is an asymmetric membrane having a tight ultrafiltration layer on the lumen side and a more open structure on the shell side.

The reactor system (Fig. 1) consists of an aqueous loop containing $300 \mathrm{~mL}$ of a $0.1 \mathrm{M}$ potassium phosphate buffer ( $\mathrm{pH} 7)$ and an organic substrate loop containing $300 \mathrm{~mL}$ triacetin as such or dissolved in toluene (autohydrolysis occurs at a $\mathrm{pH}$ above 9.5). Both loops are operated in the batch mode. Recirculation velocities in both loops are high enough to avoid mass transfer limitation and to avoid the buildup of a concentration gradient in the loop. The reactor system can be described as a perfectly mixed reactor. The organic loop is kept under 0.5 bar overpressure to avoid the aqueous phase to penetrate through the hydrophilic membrane into the organic phase. The hydrolysis products, glycerol and acetic acid, diffuse through the membrane to the aqueous phase. Reactor activity is followed continuously by titration of the produced acetic acid with a $2 M$ sodium hydroxide solution using a Radiometer $\mathrm{pH}$ stat. All reactor experiments are carried out at $30^{\circ} \mathrm{C}$ by thermostating the buffer and substrate vessel.

Experiments were first carried out in a commercially available Andante hollow-fiber membrane unit (organon, Holland). This unit consists of a symmetrical and uniform membrane (MWCO 10,000) made of regenerated cellulose and has a total surface area of $0.77 \mathrm{~m}^{2}$. Because the housing of this unit was not resistant for a long time against the organic solvents used in this study, the experimental work was continued using the highly stable Sepracor membrane reactor system. Nevertheless, some results obtained in the Andante membrane reactor will be reported.

\section{Immobilization and Startup Procedures}

Trace to $2.5 \mathrm{~g}$ lipase from $C$. cylindracea is dissolved in $500 \mathrm{~mL} 0.1 \mathrm{M}$ potassium phosphate buffer ( $\mathrm{pH} 7)$. From this solution all solids are removed by centrifugation. After cleaning the membranes in the reactor, the system is emptied. The membrane reactor is then loaded with enzyme by ultrafiltration of the enzyme solution (supernatant) over the shell side of the membrane at an overpressure of 0.35 bar. The residual amount of free enzyme that remains in the system is loaded on the membrane surface by subsequent ultrafiltration of a fresh $0.1 M$ potassium phosphate buffer. From activity measurements in the permeate it is found that all of the lipase activity was retained by the membrane during the immobilization procedure.

After the system is emptied, the shell and lumen sides of the membrane are filled with the organic substrate and with a potassium phosphate buffer solution, respectively. In the experiments performed in the cellulose hollow-fiber membrane reactor (Andante), the lipase was not immobilized at the shell side but at the lumen side of the membrane. In that reactor the organic and aqueous phases circulated along the lumen and shell sides of the membrane, respectively. The experimental procedure was practically the same as when the acrylic hollow-fiber membrane reactor from Sepracor was used.

\section{Enzyme Loading}

After membrane cleaning, the reactor is loaded with various amounts of enzyme as described in the previous section. At each enzyme loading initial reactor activity is measured using pure triacetin as the substrate phase. To compare the individual activities of the lipase in the membrane reactor and in the emulsion system, enzyme loading experiments are also carried out in a small batch, intensively mixed, emulsion reactor containing $10 \mathrm{~mL}$ triacetin and $10 \mathrm{~mL} 0.1 \mathrm{M}$ potassium phosphate buffer (pH 7).

\section{Variation of the Substrate Concentration}

The membranes are loaded with $1.25 \mathrm{~g}$ lipase from C. cylindracea as described earlier. Initial reaction rates are determined at different initial triacetin concentrations in toluene (8-100 wt \%). After the initial reactor activity is measured, the organic reactor loop is emptied and refilled with the next solution having a different triacetin concentration.

\section{Enzyme Stability}

The membrane is loaded with $1.25 \mathrm{~g}$ lipase from C. cylindracea as described before. Long-term stability of the immobilized lipase is tested in six subsequent batch runs performed over a period of 7 days at $30^{\circ} \mathrm{C}$ using pure triacetin as the substrate. After each run both the aqueous and the organic loop are emptied and replaced by a fresh buffer and substrate solution. Activity is continuously monitored as described earlier.

\section{Membrane Cleaning}

The ultrafiltration flux of a $0.1 M$ phosphate buffer ( $\mathrm{pH} 7$ ) at a transmembrane pressure of 0.35 bar was chosen as a measure to monitor the membrane status. Fouling and cleaning characteristics are studied by determining the ultrafiltration flux after each experiment (membrane charged with enzyme) and after each cleaning step (membrane without enzyme). Membrane cleaning is done with a $0.1 M$ sodium hydroxide and $1 M$ 
sodium chloride solution (Sepracor procedure). Also Ultrasil-11 (Henkel), an industrial membrane cleaning detergent, was tested $(0.1$ bar transmembrane pressure and $65^{\circ} \mathrm{C}$ ). After cleaning, a fresh lipase batch is immobilized on the membrane.

\section{RESULTS AND DISCUSSION}

\section{Immobilization}

Figure 2 shows the reactor activity as a function of the enzyme load of the Sepracor membrane reactor. The adsorption curve has the shape of a Langmuir adsorption isotherm. The optimal enzyme load is estimated to be

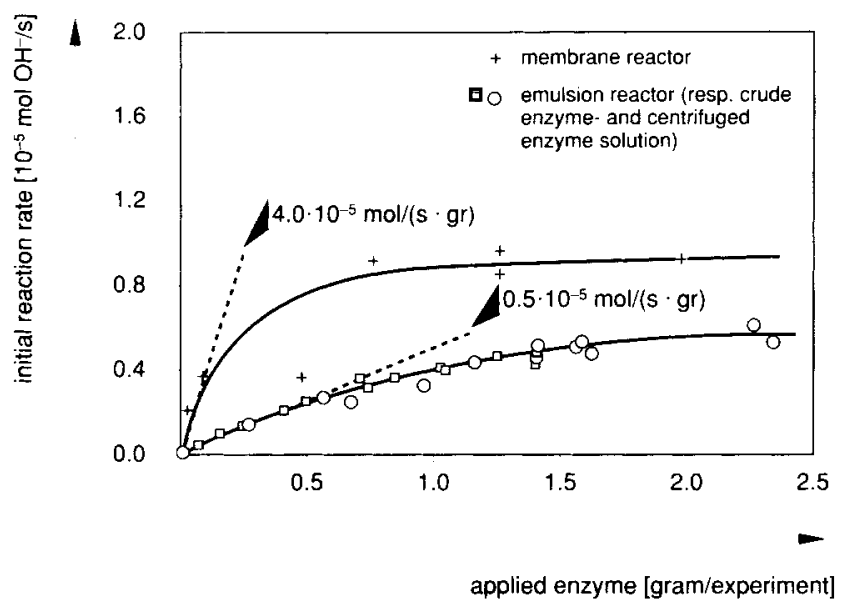

Figure 2. Total initial reaction rate as a function of applied enzyme for both the membrane reactor and the emulsion reactor.
1 to $1.5 \mathrm{~g}$ lipase from $C$. cylindracea per square meter. From Table I it can be concluded that the enzyme load applied by other investigators is in the same range. However, the optimal enzyme load is a function of the purity of the applied enzyme. Hoq et al. ${ }^{3}$ found that the optimal enzyme load of a hydrophobic polypropylene hollow-fiber membrane increased from 0.14 to $3.4 \mathrm{~g} / \mathrm{m}^{2}$ when the purity of the lipase from $C$. cylindracea decreased from 1350 to 12 units $/ \mathrm{mg}$.

\section{Kinetics}

The experimental data from the concentration variation experiments were fitted using the Michaelis-Menten model for enzyme reaction kinetics:

$$
V=V_{\max } \cdot \frac{\mathrm{TA}}{K_{m}+\mathrm{TA}}
$$

where $V$ is the reaction rate $\left(\mathrm{mol} \mathrm{OH} \mathrm{OH}^{-} / \mathrm{m}^{2} \cdot \mathrm{s}\right)$, $V_{\max }$ the maximum reaction rate $\left(\mathrm{mol} \mathrm{OH}{ }^{-} / \mathrm{m}^{2} \cdot \mathrm{s}\right)$,

TA the triacetin concentration $\left(\mathrm{mol} / \mathrm{m}^{3}\right)$, and $K_{m}$ the Michaelis-Menten constant $\left(\mathrm{mol} / \mathrm{m}^{3}\right)$.

In this equation the reaction rate is expressed as the amount of reacted ester groups per square meter of membrane area per second. For conveniency, the TA and $K_{m}$ are not expressed as surface concentrations but as bulk concentrations, assuming that the TA surface concentration is linearly related to the bulk concentration.

Figure 3 shows the Lineweaver-Burk plot for the runs performed in the Sepracor membrane reactor at differ-

Table I. Experimental results and comparison with other studies.

\begin{tabular}{|c|c|c|c|c|}
\hline Investigator & $\begin{array}{l}\text { Membrane } \\
\text { material }\end{array}$ & $\begin{array}{l}\text { Enzyme loading } \\
\qquad\left(\mathrm{g} / \mathrm{m}^{2}\right)\end{array}$ & $\begin{array}{c}\text { Activity } \\
\left(\mathrm{mol} \mathrm{OH} / \mathrm{m}^{2} \cdot \mathrm{s}\right)\end{array}$ & $\begin{array}{l}\text { Half-life } \\
\text { (days) }\end{array}$ \\
\hline Hoq et al. ${ }^{\mathrm{a}}$ & $\begin{array}{l}\text { polypropylene } \\
\text { (hydrophobic) }\end{array}$ & $0.14-3.4$ & $\begin{array}{c}2.0 \times 10^{-5} \\
\left(40^{\circ} \mathrm{C}\right)\end{array}$ & $2-15$ \\
\hline Taylor et al. ${ }^{b}$ & $\begin{array}{l}\text { acrylic } \\
\quad \text { (hydrophilic) }\end{array}$ & - & $\begin{array}{c}2.3 \times 10^{-5} \\
\left(50^{\circ} \mathrm{C}\right)\end{array}$ & $30-60$ \\
\hline $\begin{array}{l}\text { Kloosterman and } \\
\text { van Wassenaar }\end{array}$ & $(-2)-0-1$ & - & $1.4 \times 10^{-5}$ & - \\
\hline Pronk et al. ${ }^{d}$ & $\begin{array}{l}\text { cellulose } \\
\text { (hydrophilic) }\end{array}$ & 0.65 & $\begin{array}{c}1.2 \times 10^{-5} \\
\left(30^{\circ} \mathrm{C}\right)\end{array}$ & $\begin{array}{c}43 \\
\left(4 \text { at } 40^{\circ} \mathrm{C}\right)\end{array}$ \\
\hline This work $^{e}$ & $\begin{array}{l}\text { cellulose } \\
\quad \text { (hydrophilic) }\end{array}$ & - & $\begin{array}{c}1.1 \times 10^{-5} \\
\left(30^{\circ} \mathrm{C}\right)\end{array}$ & $\begin{array}{c}6 \\
\left(2 \text { at } 40^{\circ} \mathrm{C}\right)\end{array}$ \\
\hline This work $^{e}$ & $\begin{array}{l}\text { poly-acrylo nitrile } \\
\text { (hydrophilic) }\end{array}$ & $1.0-1.5$ & $\begin{array}{c}1.2 \times 10^{-5} \\
\left(30^{\circ} \mathrm{C}\right)\end{array}$ & 6 \\
\hline
\end{tabular}

Note: Where Taylor et al. (ref. 9) used lipase from Thermomyces lanuginosus, all other investigators used lipase from $C$. cylindracea immobilized in a membrane reactor (different triglycerides were applied as the substrate).

${ }^{a}$ From refs. 2 and 3. Hoq et al. found the enzyme half-life to increase from 2 to 15 days when the glycerol content of the aqueous phase increased from 0 to $18 \%$ (wt.).

${ }^{\mathrm{b}}$ From ref. 9.

${ }^{\mathrm{c}}$ From ref. 7. Lipase activity used by Kloosterman for an economic evaluation of the membrane reactor technology.

${ }^{\mathrm{d}}$ From ref. 8.

${ }^{\mathrm{e}}$ In this study different membrane materials were used. On the cellulose membrane the lipase was immobilized on the lumen side; in the acrylic membrane it was immobilized on the shell side. 


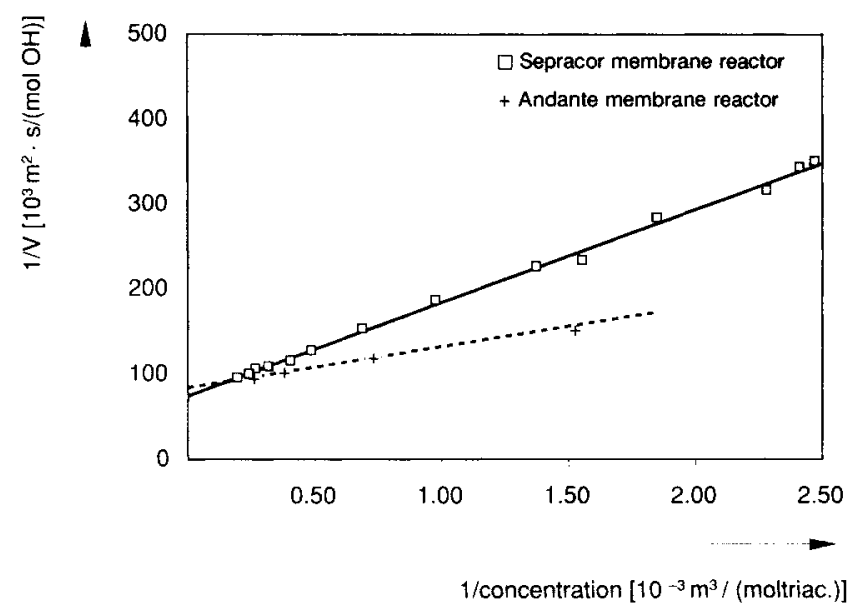

Figure 3. Lineweaver-Burk plot.

ent triacetin concentrations in toluene. Results obtained in series of increasing and decreasing triacetin concentrations were consistent, so no effect of enzyme deactivation or enzyme washout was observed during the experiment. Figure 3 shows that the studied hydrolysis reaction fully obeys Michaelis-Menten kinetics: $K_{m}=1480 \mathrm{~mol} \mathrm{TA} / \mathrm{m}^{3}$ and $V_{\max }=1.2 \times 10^{-5} \mathrm{~mol}$ $\mathrm{OH}^{-} / \mathrm{m}^{2} \cdot \mathrm{s}$. The experimental results obtained with the Andante membrane reactor are also plotted in Figure 3. The $V_{\max }$ for the Andante cellulose membrane reactor was nearly the same as for the Sepracor membrane reactor $\left(1.1 \times 10^{-5} \mathrm{~mol} \mathrm{OH}^{-} / \mathrm{m}^{2} \cdot \mathrm{s}\right)$. However, the Michaelis-Menten constant was smaller (approximately $500 \mathrm{~mol} / \mathrm{m}^{3}$ ).

Because of the problems of a low chemical resistance of the housing of the Andante membrane reactor against toluene, few experiments were carried out in this reactor, which were not reproduced. Therefore the $K_{m}$ value obtained from these experiments is not compared with the $K_{m}$ value measured in the Sepracor membrane reactor. The maximum activities measured in this study are in the same range of activities for lipase reactions in membrane reactors reported by other investigators (see Table I).

\section{Lipase Stability}

The stability of the immobilized lipase at $30^{\circ} \mathrm{C}$ was tested in a long-term experiment as described before. Figure 4 gives the reaction rate as a function of time for the Sepracor membrane reactor. From these results it was found that the enzyme deactivation followed firstorder kinetics. The half-life of the immobilized lipase from $C$. cylindracea was 6 days. In the Andante cellulose membrane reactor exactly the same half-life was measured (different membrane material and immobilization at the lumen side instead of on the shell side of the membrane). During the experiments the aqueous phase was frequently refreshed to avoid buildup in the glycerol concentration.

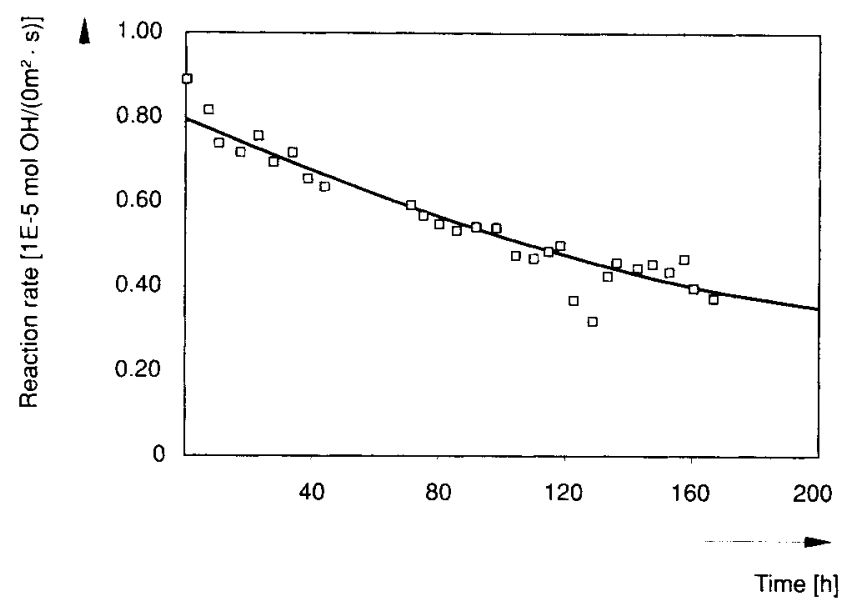

Figure 4. Enzyme stability: reaction rate as a function of time.

$\operatorname{Hoq}^{2,3}$ (see Table I) reported that the half-life of lipase from $C$. cylindracea increased from 2 to 15 days at $40^{\circ} \mathrm{C}$, when the glycerol concentration increased from 0 to $18 \mathrm{wt} \%$. In this study, running the Andante cellulose membrane reactor at $40^{\circ} \mathrm{C}$, the enzyme half-life appeared to be about 2 days, which is in agreement with the results from Hoq (see Table I).

Pronk et al. ${ }^{8}$ used the same Andante cellulose membrane reactor as applied in this study and measured a very long half-life of 43 days at $30^{\circ} \mathrm{C}$. Pronk et al. ${ }^{8}$ used the reactor in a continuous mode. Probably the glycerol concentration was allowed to build up in the experiments, leading to stabilization of the enzyme.

In the membrane reactor the immobilized lipase is situated between the organic phase and the hydrophilic membrane barrier. Through this hydrophilic membrane the aqueous phase is in close contact with the immobilized protein layer. Enzyme half-life as well as the activity of the immobilized lipase from $C$. cylindracea are comparable in the different investigations (see Table I) and do not appear to be significantly influenced by the type of membrane material applied. This observation sustains the hypothesis that the binding of the lipase to the membrane is not very specific (surface adsorption) and probably its conformation is hardly altered by immobilization. At present it is still unclear whether the lipase is active while it is adsorbed onto the membrane surface or if it exhibits its activity in the organic-aqueous interface that exists on the organic side of the membrane. In the latter case, the lipase conformation may be comparable to that in an emulsion reaction system.

\section{Comparison of the Hollow-Fiber Membrane Reactor and the Emulsion Reactor}

Figure 2 compares the overall reactor activity for both the membrane reactor and the emulsion reactor as a function of the total amount of applied enzyme per experiment. Since at low enzyme load a large excess of interfacial surface area will be present in both reactors 
it may be assumed that all the lipase is then quantitatively adsorbed in that interfacial surface area. This means that at low enzyme loads the initial reaction rate is linearly related to the total amount of added enzyme. Thus the overall initial reaction rate is not a function of the amount of installed membrane area in the membrane reactor and neither is a function of the stirring speed and the triacetin-water ratio in the emulsion reactor.

The specific enzyme activity at low enzyme load can directly be calculated from the initial slope in Figure 2, leading to specific enzyme activities of $4.0 \times 10^{-5}$ and $0.5 \times 10^{-5} \mathrm{~mol} / \mathrm{s} \cdot \mathrm{g}$ for the membrane reactor and the emulsion reactor, respectively. It is concluded that for the present reaction system the specific enzyme activity in the membrane reactor is significantly higher than in the emulsion reactor.

Because of the Langmuir adsorption characteristics and the Michaelis-Menten kinetics of the lipase observed in the membrane reactor, it is expected that the mechanism of the lipase kinetics is similar to that of the reaction kinetics of the lipase in its "natural" environment, e.g., the emulsion system. Also the indications that lipase binding to the membrane is not specific and the lipase may exhibit its activity in the native form support the conclusion that the lipase reaction in the membrane reactor and in the emulsion reactor are quite similar.

The lower specific activity found in the emulsion reactor may be the result of a large lipase fraction present in the aqueous phase (where the lipase does not exhibit activity), due to the partitioning of the lipase over the aqueous phase and the aqueous-organic interface. In the membrane reactor the aqueous bulk phase will be practically absent on the organic side of the membrane, and, therefore, practically all of the lipase will be present in the aqueous-organic interface. Also, a different lipase packing in the aqueous-organic interface of both reactors may be the reason for the different activities observed in both reactors.

\section{Membrane Regeneration, Membrane Fouling, and Reactor Stability}

Membrane fouling can be a serious problem in running the membrane reactor. In Figure 5 it can be seen that the Sepracor membranes were irreversibly fouled when the Sepracor procedure for membrane cleaning was applied (using a $\mathrm{NaOH} / \mathrm{NaCl}$ solution). After four regeneration cycles the membranes were completely clogged. From run 4 to 12 an additional membrane cleaning was performed using a $0.5 \mathrm{wt} \%$ Ultrasil-11 solution. Figure 5 shows that using this new cleaning procedure the membrane permeability was fully restored. Also the lipase immobilization appeared to be more reproducible. Our experience is that long-term use of the hollow-fiber membrane reactor is possible. In this study the membranes were regenerated 12 times over a period of 6 months without showing any aging effects.

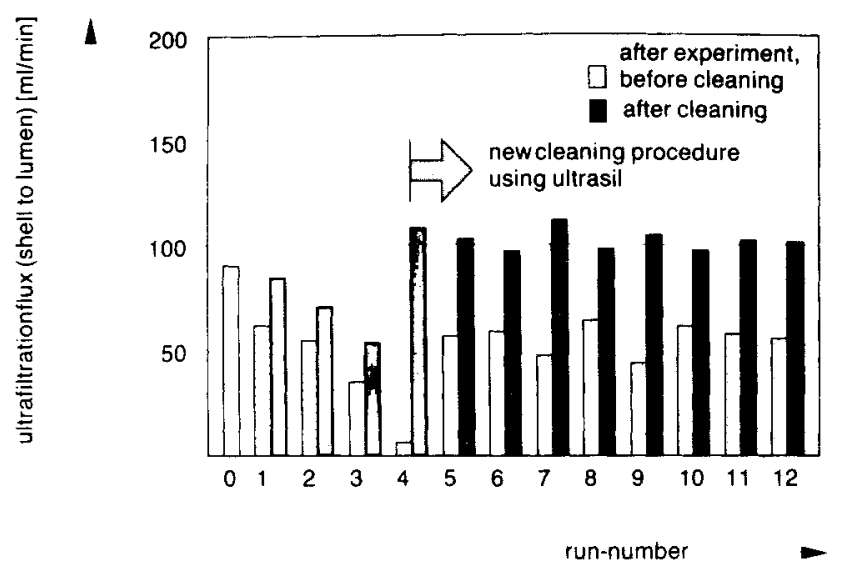

Figure 5. Membrane fouling and membrane cleaning characteristics.

\section{CONCLUSIONS}

Immobilization of lipase from $C$. cylindracea (Sigma) on a polyacrylic nitrile membrane follows a Langmuir adsorption model with an optimal enzyme loading of about $1.0-1.5 \mathrm{~g} / \mathrm{m}^{2}$. Reaction kinetics of the immobilized lipase obeys Michaelis-Menten kinetics defined on the membrane interfacial area $\left(K_{m}=1480 \mathrm{~mol} \mathrm{TA} / \mathrm{m}^{3}\right.$ and $\left.V_{\max }=1.2 \times 10^{-5} \mathrm{~mol} \mathrm{OH}^{-} / \mathrm{m}^{2} \cdot \mathrm{s}\right)$. At $30^{\circ} \mathrm{C}$ enzyme half-life is 6 days.

Enzyme loading, activity, and stability are comparable with the findings of several other investigators (all using different triglycerides as the substrate) and seem to be independent of the type of membrane material used. This observation supports the hypothesis that the lipase binding is not very specific and probably its conformation is hardly affected by immobilization.

In the present study the specific activity of the immobilized lipase is significantly higher compared to the specific activity of the lipase in the emulsion reactor, probably due to a different lipase packing in the membrane interfacial area and/or a slightly different molecular conformation and/or a partitioning effect of the lipase over the emulsion interfacial area and the aqueous bulk phase (lower efficiency). In this study the membranes of the hollow-fiber membrane reactor could be cleaned 12 times (over a period of 6 months) using Ultrasil-11 as the membrane cleaning detergent without showing any decline in the reactor performance.

The long-term stability, the high specific lipase activity, the separation of the aqueous and organic phases, and the fact that the lipase is efficiently immobilized makes the hollow-fiber membrane reactor very promising for stereoselective lipase-catalyzed reactions in the production of high-value products, e.g., pharmaceuticals. Further it is concluded that due to the presence of a fixed interface, the hollow-fiber membrane reactor may be a suitable tool to assess lipase kinetics in a fast and convenient way.

At present the lipase-catalyzed resolution of a racemate is under investigation at DSM-Research. 
The authors thank Professor K. van't Riet and Ir. W. Pronk from the Agricultural University Wageningen for their advice.

\section{References}

1. Benzonana, G., Desnuelle, P. 1965. Biochim. Biophys. Acta 105: 121.

2. Hoq, M. M., Koike, M., Yamane, T., Shimizu, S. 1985. Agric. Biol. Chem. 49: 3171.

3. Hoq, M. M., Yamane, T., Shimizu, S., Funada, T., Ishida, S. 1985. JAOCS 62: 1016.

4. Kamphuis, J., Kloosterman, M., Schoemaker, H. E., Boesten, W. H. J., Meijer, E. M. 1987. Proc. 4th Eur. Congr. Biotechnol. 4: 331 .
5. Kierkels, J. G.T., Vleugels, L. F.W., Kern, J. H. A., Meijer, E. M., Kloosterman, M. 1990. Enz. Microb. Technol. 12: 760763.

6. Kloosterman, M., Elferink, V.H.M., van Iersel, J., Roskam, J. H., Meijer, E. M., Hulshof, L. A., Sheldon, R. A. 1988. Trends Biotechnol. 6: 251.

7. Kloosterman, J., van Wassenaar, P. D., Bel, W. J. 1987. Fat Sci. Technol. 89: 592.

8. Pronk, W., Kerkhof, P. J. A. M., van Helden, C., van't Riet, K. 1988. Biotechnol. Bioeng. 32: 512.

9. Taylor, F., Panzer, C. C., Craig, J. C., Jr., O'Brien, D. J. 1986. Biotechnol. Bioeng. 28: 1318. 